\title{
LETTERS
}

\section{Author Response to "Considerations for Determining Perceived Benefits and Challenges of Student Organizations at Pharmacy School Satellite Campuses"}

\author{
Mollie Ashe Scott, PharmD, ${ }^{\mathrm{a}}$ Jacqui McLaughlin, PhD, ${ }^{\mathrm{b}}$ Greene Shepherd, PharmD, ${ }^{\mathrm{a}}$ \\ Charlene Williams, PharmD, ${ }^{\mathrm{a}}$ Jackie Zeeman, PharmD, ${ }^{\mathrm{b}}$ Pamela U. Joyner, EdD, MS Pharm ${ }^{\mathrm{b}}$ \\ ${ }^{a}$ UNC Eshelman School of Pharmacy, Asheville, North Carolina \\ ${ }^{\mathrm{b}}$ UNC Eshelman School of Pharmacy, Chapel Hill, North Carolina
}

To the Editor: We appreciate the thoughtful response by Dr. Ayers to our publication that assessed the structure of student organizations on pharmacy school satellite campuses. ${ }^{1}$ Her personal experiences on a satellite campus during her pharmacy education are valuable and insightful.

We agree that the size of the student body is of utmost importance when establishing and expanding student organizations on satellite campuses. Unfortunately, there is a gap in the literature with respect to determining the optimal number of members per organization that predicts success. Although colleges and schools with a large student body are more likely to offer a multitude of cocurricular experiences due to bandwidth, size does not guarantee that the organizations positively impact the professional development of student pharmacists. Consequently, it is imperative that student organizations are developed strategically, align with core competencies, and create opportunities for students to further develop their skills as clinicians and leaders outside of the classroom. The 2016 Accreditation Council for Pharmacy Education (ACPE) standards emphasize four key elements that promote personal and professional development including self-awareness, leadership, innovation and entrepreneurship, and professionalism. ${ }^{2}$ Because satellite campuses are often smaller than main campuses, it is important to favor quality of the co-curriculum over quantity of events to ensure that these attributes are fully developed.

Our study focused on the perceptions of satellite campus administrators about student organizations. ${ }^{3}$ Dr. Ayers notes that students on satellite campuses might have different viewpoints about benefits and challenges of the cocurricular experience. ${ }^{1}$ In 2015, Adams and colleagues published a paper entitled "Student pharmacists' perceptions of access to student organization opportunities at colleges/ schools of pharmacy with satellite campuses." compared perceptions of and satisfaction with access to student organization opportunities between students at main versus satellite campuses among four schools of pharmacy that offered the entire doctor of pharmacy curriculum on multiple campuses. Three hundred fourteen second- and third-year students completed an 18-item online survey (31\% response rate), and $22.9 \%$ of respondents were from a satellite campus. The number of students per class on the satellite campuses ranged from 10 to 40 students. More students on the main campus agreed that they had access to faculty advisors, that activities were offered equally on each campus, and that it was easy to communicate with students on other campuses. These findings highlight the importance of creating unity and equity within a "one school, multiple campus" environment. As the number of satellite campuses grow, it is important to develop best practices for structuring and supporting student organizations on small and large campuses alike. Additional research to evaluate student perceptions about challenges and benefits of professional organizations on satellite campuses is warranted.

The co-curricular experience is an important component in the professional development of future pharmacy leaders, and must be strategically developed on satellite campuses and mapped to educational outcomes in the ACPE standards. ${ }^{2}$ Focus should be on the quality of outreach events and professional activities, rather than on the quantity of events that are held.

\section{REFERENCES}

1. Ayers G. "Letter to the Editor." Am J Pharm Educ. 2017;81(2): Article 39.

2. Accreditation Council for Pharmacy Education. Accreditation standards and key elements for the professional program in pharmacy leading to the doctor of pharmacy degree. "Standards 2016." https:// www.acpe-accredit.org/pdf/Standards2016FINAL.pdf. Accessed November 9, 2016.

3. Scott MA, McLaughlin J, Shepherd G, Williams C, Zeeman J, Joyner P. Professional organizations for pharmacy students on satellite campuses. Am J Pharm Educ. 2016;80(5):Article78.

4. Adams EN, Conry MJ, Heaton PC, Ramsinghani S, Rodgers PT, Eddington ND. Student pharmacists' perceptions of access to student organization opportunities at colleges/schools of pharmacy with satellite campuses. Curr Pharm Teach Learn 2015;7(2):185-191. 